University of Rhode Island

DigitalCommons@URI

Open Access Master's Theses

1981

\title{
A REGIONAL APPROACH TO LAND USE PLANNING IN THE CATSKILLS
}

Barry Howard Wershaw

University of Rhode Island

Follow this and additional works at: https://digitalcommons.uri.edu/theses

\section{Recommended Citation}

Wershaw, Barry Howard, "A REGIONAL APPROACH TO LAND USE PLANNING IN THE CATSKILLS" (1981). Open Access Master's Theses. Paper 499.

https://digitalcommons.uri.edu/theses/499

This Thesis is brought to you for free and open access by DigitalCommons@URI. It has been accepted for inclusion in Open Access Master's Theses by an authorized administrator of DigitalCommons@URI. For more information, please contact digitalcommons-group@uri.edu. 


\section{A REGIONAL APPROACH TO LAND USE PLANNING \\ IN THE CATSKILLS}

BY

BARRY HOWARD WERSHAW

A THESIS PROJECT SUBMITTED IN PARTIAL FULFILLMENT OF THE

REQUIREMENTS FOR THE DEGREE OF

MASTER OF COMMUNITY PLANNING

UNIVERSITY OF RHODE ISLAND

1981 


\section{MASTER OF COMMUNITY PLANNING THESIS PROJECT}

OF

BARRY HOWARD WERSHAW

APPROVED :

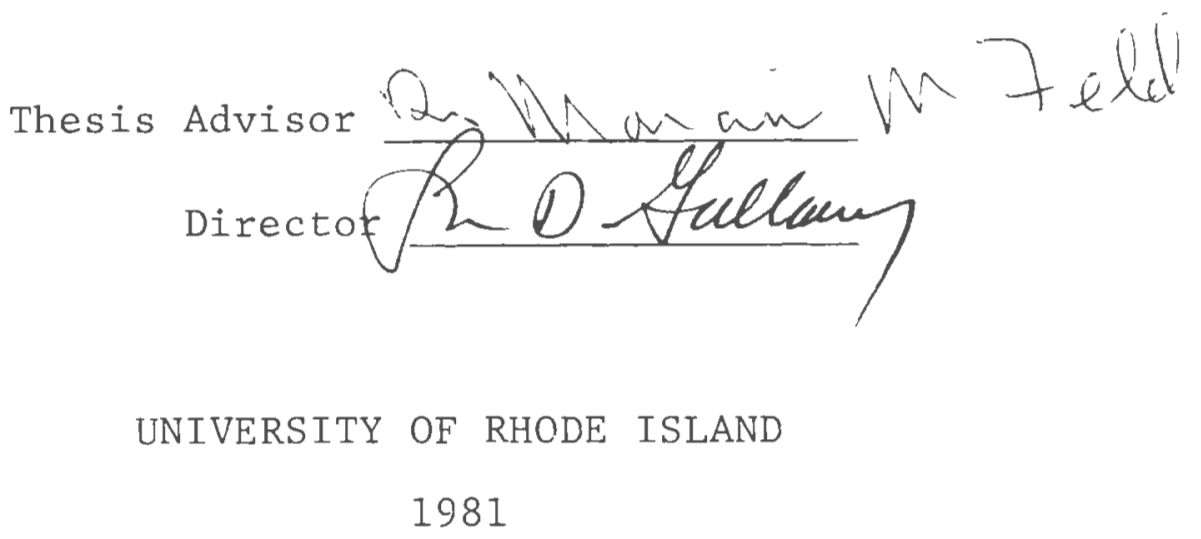




\section{ACKNOWLEDGEMENTS}

This study is a reflection of my concern for the preservation of the Catskill Region. I "discovered" the Catskills eight years ago and have been in awe of them ever since. It only seems appropriate that I devoted my thesis research to this topic.

However, the successful completion of this research would not have occurred without the assistance of Thomas Miner, of the Catskill Center for Conservation and Development. I will also be forever grateful to Dr. Marcia Marker Feld for her patience, helpful advice and assistance that was offered to me in this study as well as during my entire graduate education. 
TABLE OF CONTENTS

INTRODUCTION . . . . . . . . . . . . . . . . . 1

I DESCRIPTION OF CATSKILL REGION...........4

II ENVIRONMENTAL PROBLEMS AS A RESULT

OF DEVELOPMENT.................... 12

III COUNTY AND LOCAL PLANNING ACTIVITIES

IN THE CATSLILLS................... 20

IV PROPOSED SOLUTION.................. 29

$\mathrm{v} \quad$ CONCLUSION........................ 41 


\section{Introduction}

The Catskill region of New York State is known to the world as the setting of Washington Irving's tales of Rip Van Winkle and as the home of lavish resorts. The term "Catskills" also depicts an image of beautiful forested mountains and streams with hunters and fisherman roaming the land. To some, the Catskills brings back recollections of the Woodstock generation of a decade ago.

The Catskills as a recreation and resort area obscures the full extent of the region. It has more than magnificent mountains and streams. A diverse agricultural economy produces dairy products, poultry and eggs, vegetables and fruits.

"The Catskill region is also known to a more limited number of people as a beautiful rural area that is in imminent danger of being overtaken by an advancing surge emanating from the New York City metropolitan area. Productive dairy and truck farm, mountain slopes and peaks, clear trout streams of unmatched quality and the historical and cultural traditions of rural villages stand face to face with the kind of modern 1 and development practices that have destroyed rural lifestyles and caused severe environmental problems in other scenic areas of the country." 1

A combination of the natural environment, proximity to large population centers and easy access over improved roads and express highways has made the Catskill region exceptionally desirable for development. Marginal farm and other land is 
marketed at increasing prices for subdivision and development. Demand continues and often results in unplanned, uncontrolled development. This in turn has caused serious environmental problems that is rapidly destroying the scenic, aesthetic, and rural character of the Catskills..

It is within this context that the Catskill Region will be studied. The primary purpose of this study is to explore these areas of concern and discuss the possible solutions that can help preserve the scenic and rural character of the Catskills.

There are five sections to this study. The first section will be a general description of the Catskill Region, This will include defining the study area, as well as describing population and housing characteristics. It will also deal with an analysis of recreation, agriculture and industry.

The second section identifies and analyzes the current land use problems that confront the Catskill region. Commercial and residential development is creating a negative impact on the land in the form of highway strip development and residential subdivisions. In analyzing the potential for develonment, it appears that some development projects occuring in areas that are environmentally sensitive and unable to sustain major physical development.

The third section assesses the current status of planning in the Catskill Region from a regional, county and local perspective with comments on the problems that exist regarding the lack of funds and resources available to the Region in terms of planning capabilities. 
The fourth section is an analysis and critique of the proposed solutions to protect and manage the Catskill Region's land. The findings and recommendations of the Temporary State Commission to Study the Catskills was the first attempt at providing a basis for effective land management and sound land use planning.

The last section of this study will examine the major findings and recommendations of the Department of Environmental Conservation. The DEC believes that an improved institutional and operational framework for land management is necessary to guarantee the future viability of the Catskill Region. 
Description of Catskill Region

The Indians called it Onteora- Land in the Sky. It is called Catskill- from the Dutch word Kaats-kill for cat's creek. In attempting to define the physical boundaries of the Catskill region a quote from The Catskills seems appropriate.

"It is not easy to define the boundaries of the Catskill Mountains. I once asked a man who lived within the shadow of Plattekill Mountain just where the Catskills began. "You keep on going," he said, "until you get to where there's two stones to every dirt. Then, b'Jesus, you're there. "2

However for the purpose of this study, the Catskills will encompass an area that is roughly fifty miles east to west and fifty miles north to south. It is situated between the Hudson and Delaware Rivers, and contains all of the counties of Sullivan, Ulster, Greene and Delaware as well as the southern tip of Schoharie County(See Map). The region spans more than 6,000 square miles, over 4,000,000 acres. Within it lies the Catskill Park, consisting of 675,000 acres within the "blue line" oark within whose boundaries lie both private and forest preserve lands that are protected as "forever wild" by the New York State Constitution.

Article XIV, Section 1 of the New York State Constitution, except for minor specific variances, provides the basic policy guideline by stating that "forest preserve as now fixed by law, shall be forever kept as wild forest lands. They shall not be leased, sold or exchanged, or be taken by any corporation, public or private, nor shall the timber theron be sold, removed or destroyed."

The physical character of the Catskill region makes it a unique area of the state. Approximately 241,000 acres or over 
$95 \%$ of the Catskill Forest Preserve lies within the Catskill Park. The wild character of the Catskill Forest Preserve varies from somewhat remote and trailess mountain peaks and streams to intensely used camping areas and trails. More than 7,100 acres of Catskill Forest Preserve exist outside the Catskill Park boundary. This land is in the form of 198 detached parcels, scattered throughout the counties of Sullivan, Delaware, Greene, and Ulster.

In the area of water resources, the headwaters of the Delaware and Susquehanna Rivers begin in the Catskills upland slopes. In addition the Catskills includes six reservoirs and supporting watersheds that supply the New York metropolitan area with $89 \%$ of its daily drinking water needs. A variety of small and medium-sized industries is located throughout the region, with clustering near the only two cities of Kingston and Oneonta.

\section{Population Growth}

In general, population statistics providea measure of growth or decline of a region. Basic population statistics were available from both the U.S. census and New York State Office of Planning Services. However, these census figures account for year round residents only and do not include the large influx of seasonal residents and vacationers who stay in the many Catskill resorts.

Both of the above groups, vacationers and seasonal residents have had a significant effect on the land by causing the growth of private facilities such as: camp sites, golf courses and ski centers. The impact which seasonal residents have had 
Table I

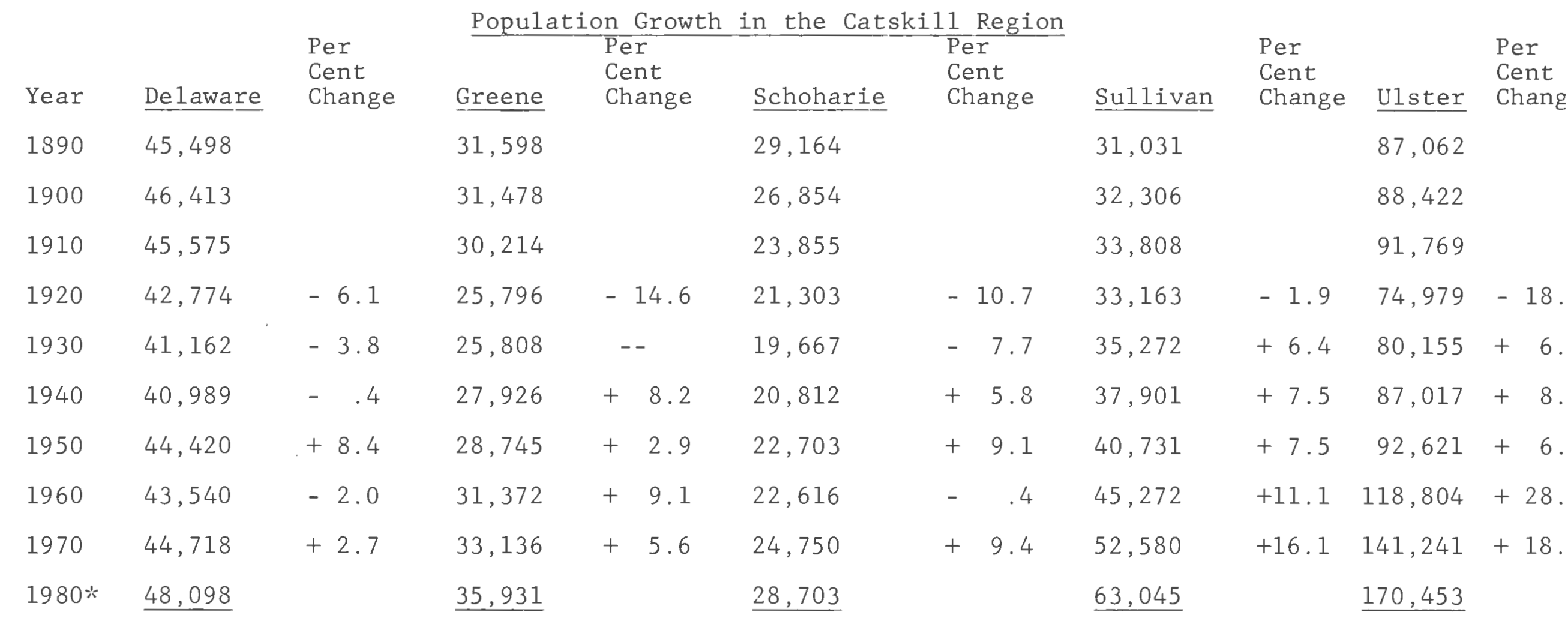

Catski11 Region Total Population - 1960 - 261,605

$1970-296,4.25$

Source: United States Census

*Source: New York State Office of Planning Services Demographic Projections Population figures for year round residents are shown in Table I 
on land use is also significant steming from the surge of second home development. "In Sullivan County, nearly ten times as many subdivision lots were approved in 1972 as in 1969-a circumstance which is largely related to the growth of second home development" 3

The 1970 census showed a population increase over the past decade of almost 19 per cent in Ulster County and over 16 per cent in Sullivan County, compared with a statewide average increase of 8.4 per cent. Some small towns and villages, caught in the development wave, have doubled since 1960.

Table II indicated the density of population for 1960 and 1970 .

\section{Housing Growth}

In the years between 1960 and 1970 there was a reduction of the housing supply in the Catskill region. For example,in U1ster County between 1969 and 1970, household population increased by $18.9 \%$ but total housing units increased by only $12.9 \%$. The change in the number of housing units between 1960-1970 is shown in Table III.

Analysis of the information indicates that in 1970 the average number of seasonal units for the Catskill region is almost 20 per cent. In Sullivan County alone, 53 per cent of all housing units are seasonal. Although the number of seasonal units in 1970 was almost 20 per cent, it shows a significant decrease from 1960. Figures in Table III do not provide an explanation of this phenomenon, but field experience indicates this trend is partly a result of the conversion of seasonal to year round units 
Table II

Density of Population

County

Delaware

Greene

Schoharie

Sullivan

Ulster
1960 Population

Per Square Mile
1970 Population

Per Square Mile

30.7

50.7

39.7

53.6

123.8

Source: New York State Office of Planning Services

New York State Minor Civil Division Profile Series 非 August 1971

Table III

1960 - 1970 Housing Status by County

County

Delaware

Greene

Schoharie

Sullivan

Ulster
Total Number Units 1960
Year Round Units Seasonal Units* $19601970 \quad \overline{1960}$

$12,817 \quad 16,359$

$9.6 \%$

9,777

6,576

14,112

36,067
14,054

15,317

8,923

47,401

55,739

45,020

49,359

* As a percentage of total housing units

Source: 1960,1970 Census of Housing \& N.Y.S. Office of Planning

Services Minor Civil Profile Series \#1 August 1971 
particularly in the more rural counties." 4

Although there has been a reduction of the housing supply and a change in the character of housing, the significant growth in subdivisions and lots continues.

What might prove to be a response to the decreasing housing supply is the rapid increase in mobile homes. Table IV shows the increase in the number of mobile homes.

As indicated in table IV the increase in the number of mobile homes has been significant. This may also be the result of the dramatic rise in the cost of buying a house.

"The Catskill region counties have two or three times the New York State average precentage of mobile homes as compared to total year round housing units." 5 In addition, three of the Catskill region's counties(Greene, Sullivan and Schoharie) are in the top ten of the state's counties with the largest percentage increase in the number of mobile homes from 1960 - 1970.

As part of a visual survey of the Catskill region, it has been noted that in most cases, mobile homes are located on individual lots rather than in mobile home parks under permit. For example, "there were 995 mobile homes in Delaware County. Of these only 249 mobile homes were located in parks under permit. Therefore one may conclude that in 1970, Delaware County found $75 \%$ of mobile homes on individual lots or in parks not under permit. " 6

The significance of this data will be discussed later in the study in a discussion of land development concerns. 


\begin{tabular}{c} 
Table IV \\
Year Round Occupied Mobile Homes 1960 - 1970 \\
\hline
\end{tabular}

$\begin{array}{lcrcc}\text { County } & \begin{array}{l}\text { Number of Mobile Homes } \\ 1960\end{array} & 1970 & \begin{array}{r}\text { Percent increase } \\ 1960-1970\end{array} & \begin{array}{l}\text { As Percent of } \\ \text { Year Round } \\ \text { Housing } 1970\end{array} \\ \text { Delaware } & 368 & 995 & 170.4 \% & 6.1 \% \\ \text { Greene } & 151 & 568 & 276.2 & 4.5 \\ \text { Schoharie } & 155 & 567 & 265.8 & 7.0 \\ \text { Sullivan } & 252 & 948 & 276.2 & 4.3 \\ \text { Ulster } & 683 & 2,168 & 217.4 & 4.4\end{array}$

New York State
Total 31,188
66,523
$113.3 \%$
$2.17 \%$

Source: New York State Office of Planning Service Facts on Mobile Homes, March 1972 


\section{Footnotes}

1. The Natural Resources Defense Council, 1975, Land Use Controls in New York State: A Handbook on the Legal Rights of Citizens, Elaine lioss ed. p. 133.

2. Evers, Alf, 1972, The Catskills: From Wilderness to Woodstock Doubleday, p. 32

3. Op. Cit. The Natural Resources Defense Council, p. 134

4. Temporary State Commission to Study the Catskills: Interim Report: 1974, p. 13.

5. Ibid p. 13

6. Ibid p. 13 
Chapter II

Environmental Problems as a Pesult of Development

The Catskill Region may be known for its scenic beauty that boasts clear trout fulled streams and picturesque hamlets, however this does not preclude the growing land use problems facing the entire region. Incompatible land use is causing severe environmental damage to the areas vital resources. "The social and economic well being and the general welfare of the residents of the Catskill Region, and of the people of the state generally are critically dependent upon the preservation, enhancement, protection and wise use of the Catskill region's natural, scenic, aesthetic, ecological, historic, recreational and open space resources.However the abundance variety and quality of these resources have been reduced, and in some cases have already been seriously impaired by the pressure of a growing and more mobile population, development activities by a wide variety of persons including state agencies, the increased use of advanced technology, unsound or substantially unregulated development practices and a lack of sound overall land management in the region." 1

It is the intent of this chapter to identify and analyze those problems that confront the Catskill region. There seems to be two distinct areas of concern when defining these problems. Unplanned development and poor land management are perhaps the most significant issues in the region. This chapter will address these two areas separately although they are integrally related.

Serving as the source of $89 \%$ of New York City's drinking water, the Catskill waterways form the Catskill reservoirs which 
are vital to the State of New York. Additionally, the Catskill waterways serve as recreational facilities for fishing, swimming and boating to the millions of vacationers, thereby providing a principal basis for economic activity in the region.

However, the water quality of the Catskills has been seriously threatened due to major changes in land use which include for instance the shift from mountain dairy farms to recreational property. Pollution, largely from agricultural activity, and pollution from an increasing number of primary and secondary homes built to take advantage of the region's scenic views, presents a continuing threat to the area's waterways. Another problem of concern to the region is the reduction of agricultural land. Agriculture as an economic activity is vitally important to the region's economy.

The environmental attractiveness of the Catskill Region is one reason for the increasing pressure on agricultural land. Demand for land for development has driven market value above its value for farming, with the added effect of increased assessed valuation. New land values, interacting with other economic and social variables have caused a decline in the region of the total number of farms.

There is currently a lack of confidence in the future of agriculture among farmers. The reluctance to make capital investments and the turning of young, people to other occupations are among the reasons for the decline.

What may be more of the cause than the effect of land use 
problems in the Catskill Region is rapid land development. This has been brought upon by an increasing number of homes for both commuters and vacationers which involves subdivision of land. New York City's suburbs have advanced steadily northward toward the lower perimeter of the Catskill region. The opening of major highways has placed lower Sullivan County within commuting distance of Manhattan. A vigorous second home market exists for those who want to spend weekends and vacations in the Catskills. The fact that the lower Catskills are within the range of one tank of gasoline for motorists may become increasingly more important for this market, as fuel prices increase.

Although some towns and villages have doubled in population since 1960, this does not reflect second home development or seasonal use.

Tax assessment practices in New York State, in which land is usually assessed according to its potential for development rather than its existing use, encourage owners of large tracts of land to sell or develop their properties. Many farmers and other land owners who hold highly taxed acreage that does not generate sufficient income, come under increasing pressure to se11. Thus, the number of farms in the Catskill Region is rapidly dwindling, and the land speculation companies are showing an increased interest in the area.

"Strip development" and subdivisions are two types of development around which many problems revolve. In the Catskills, strip development takes place along major access roads. Ice cream stands, mobile home courts, gasoline stations, and shops 
have sprung up along major highways. People have then sought homes within easy reach of the services offered by such establishments.

"This kind of development is a particular problem in the Catskills, since the major highways generally trace the paths made by tanners in the early nineteenth century through very narrow valleys. These valleys very quickly become crowded by competing land uses. Major construction projects begin to creep up mountain slopes, where the land is not suitable for development" 2

In the valleys, development continues in piecemeal fashion often in subdivisions of fifteen to thirty lots which are financed by local residents under pressure from rising taxes. The total effect of several developments can be severe.

In analyzing the potentials for development in the Catskill Region, the New York State Department of Environmental Conservation had developed a set of elements which are important in making determinations for sound development. These included reviewing residential construction, local roads and streets. Properties evaluated were the water table, flood hazard, slope, and other significant physical factors. The most limiting properties affecting any of the elements were used in designating the degree of limitation.

Four degrees of limitations were defined:

Slight - Indicates the land has properties favorable for development. Physical limitations are minor and can be easily overcome. Good performance and low maintenance can 
be expected.

Moderate - Indicates the land has properties moderately favorable for development. Limitations can be overcome or modified with special planning, design or maintenance. During some seasons of the year, the structure or planned use may be somewhat less than desired.

Severe - Indicates the land has one or more unfavorable properties. Limitations are difficult and costly to modify or overcome requiring special design or intense maintenance. Very Severe - Indicates the land has unfavorable properties of such magnitude that they are extremely difficult and costly or impractical to overcome.

"The mountaineous characteristics of the Catskills are reflected in the very high percentage of land that has severe and very severe limitations. Most areas that have very severe ratings are characterized by very steep slopes(generally above $35 \%)$. The very severe areas where slopes are not a factor are in flood prone areas along streams or are in wetland areas.

The most common areas with severe limitations are characterized by moderate to steep slopes(3-25 percent). Rolling hills are the sites having moderate limitations for development. These sites have gentle slopes ranging from 3-15 percent. The best sites with slight limitations are scattered and comprise a relatively small area within the Catskills. Typically they are found on the valley terraces above the flood plains." 3 


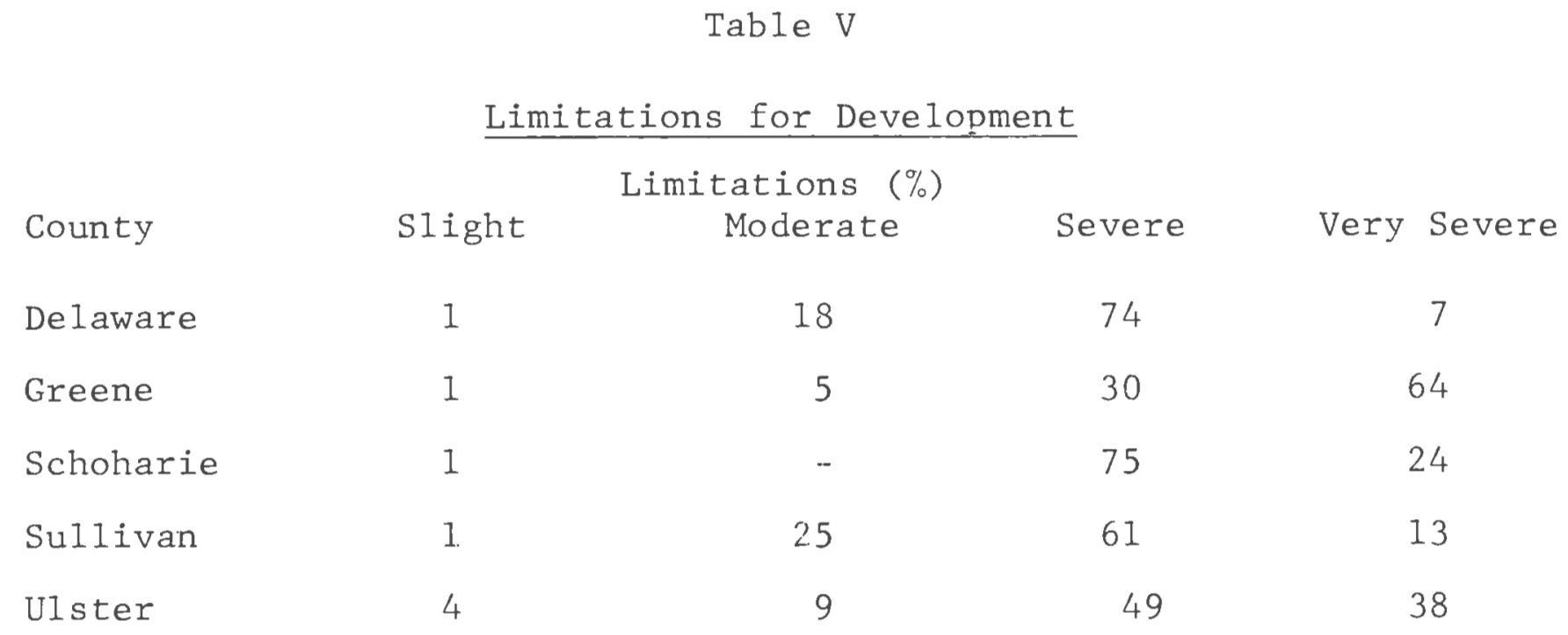

Source: Department of Environmental Conservation 1976 
While there are scattered examples of well planned environmentally sensitive subdivisions in the Catskill Region, many projects have caused real damage to land resources. The environmentally sensitive nature of much of the land in the area along with the failure by developers to abide by state regulations dealing with the proper location and installation of solid waste facilities has led to many serious problems.

In many cases the question arises of whether the land used for subdivisions is actually capable of sustaining the human habitation placed upon it.

These are only some of the issues and concerns threatening the future of the Catskills. One question which can be asked is "Why is this occurring and how might the management of the Catskills land be conducted more efficiently"?

Much of the problem rests with the absence of local land use controls which are often the only means of protecting a locality from unplanned growth. However, the use of local land use controls does not cover the adverse effects of large scale developments which cross local boundaries, that in the absence of regional comprehensive planning and land use controls are the greatest threat to the future of the Catskill.

The next section of this study describes current planning efforts in the Region and assesses the limited effectiveness of this effort. 


\section{Footnotes}

1. New York State Assembly Bill 作7884, March 29, 1977.

2. The Natural Resources Defense Council, 1975, Land Use Controls in New York State. Elaine Moss edition. p. 134.

3. New York State Department of Environmental Conservation, Analyzing the Potential for Community Development and Agriculture in the Catskill Region, Albany, 1976 p.8. 


\section{Chapter III}

County and Local Planning Activities in the Catskills

There is no overall comprehensive planning program for the land and water resources of the Catskill region, however a limited amount of planning is conducted at the county and local levels in the Catskill counties of Delaware, Greene, Schoharie, Sullivan and Ulster. Land use planning in the Catskills is not taking place in all communities nor is it being conducted in accord with particular standards that lend themselves to a regional approach to land management.

The main thrust of this section is to describe the current status of planning in the Region.

At the present time, all the counties of the Catskill Region have county planning agencies and at least one full-time professional staff member. Nevertheless, planning efforts vary a great deal from county to county.

Although many individual problems would be identified for county planning agencies, most can be summarized in one phrase a lack of funds and resources to exercise their powers.

"Federal funds channeled through the state are available once the county decides to sponsor a planning, agency and many county planning efforts do or plan to receive these funds. Nevertheless, the viability of a county planning effort is dependent on more than a "one man operation." In most counties, the problem is not so much getting started but expanding the planning effort sufficiently to assume meaningful county wide 
and local assistance responsibilities."

The legislative mandate for county planning agencies needs simplification and clarification. Does a county planning agency have an advisory, planning, review and/or regulatory functions? Is it realistic to expect any county planning agency to assume all these responsibilities ? The responsibility of the county planning agency in relation to localities is somewhat restricted in terms of review powers. Counties are given some powers over communities but not enough to effectively guide or enforce county wide policies.

The legal powers of county planning agencies are divided into four major categories - advisory, planning, review and regulatory functions.

Advisory Assistance: "A county planning agency may "collect" and distribute information relative to metropolitan, regional, and community planning and assist communities in the development of a zoning ordinance." 2

Currently among the 75 towns in the region only $36 \%$ have zoning ordinances. One possible reason for the limited use of zoning as a tool for controlling growth is the limited professional staff within the counties who serve in the capacity of an advisory and assistance body. There is one non-profit interest group in the Catskills, the Catskill Center for Conservation and Development, that collect and distributes information relative to the physical, social, and economic issues confronting the entire Catskill Region. However, there is one professional on its staff. At times, the Catskill Center 
receives assistance from interns who provide manpower to conduct studies in a variety of functional areas common to the Region. This however is done on a limited basis due to the lack of funds available to them.

The importance of an advisory and technical assistance function should not be under estimated. It is necessary before any planning review of regulatory requirements are initiated.

In the Catskills, many of the questions that need answering are common to the entire region. The county planning agencies are the sole source of assistance to which localities may turn to seek advice.

Planning : County planning agencies are authorized to "prepare and adopt a comprehensive master plan for the development of the entire area of the county which must include highways, parks, parkways and all other public sites and facilities." The elements of the comprehensive plan dealing with the public sites and facilities to be developed by the county are legally binding once adopted by the county legislative body. The plan may include other elements but these are not officially adopted and are of a guideline nature only.

Since the county comprehensive plans legally bind only the public lands, the privately owned lands are defacto given "carte blanche" regarding any future development. Although a large amount of land is publicly owned, much of it is in private ownership with no vehicle to guide its future development.

Review: County planning boards are required to review 
proposed municipal zoning ordinances or amendments, and applications for special permits or variances, and may be given the power to review the subdivision plats by the county legislature. However, these review authorities are confined to land lying within 500 feet of any of the following:

1. City, village or town boundary

2. Existing or proposed county or state park or other recreation area;

3. The right of way of any existing or proposed county or state highway or road;

4. The right of way of any existing or proposed county

5. The existing or proposed boundary of any county or state owned land containing a public building. 3

For the towns that have zoning ordinances, the county planning boards are restricted in their review powers by only having authority to review zoning ordinances, applications, and subdivisions plats within a specified radius rather than having review authority for their entire county.

In analyzing the review power of the county planning agencies, it appears that a physically limiting boundary for which they have authority to review, may permit development in areas that should not be developed.

Regulatory: County legislatures can empower the county planning board to adopt subdivision regulations for certain areas in the county. However, this county power would not apply to areas within a town's jurisdiction unless the town so desires and approves. None of the Catskill counties' planning boards have received this power. Consequently, there are no countywide 
subdivision regulations in effect in any way of the Catskill counties. Because New York State does not provide for county ordinances, there are no other county level land use controls of any kind in effect in the Catskill counties.

The power of the county planning boards as a regulatory body is further restricted in that they do not have the power to adopt subdivision regulations within their jurisdiction. The home rule authority granted to the towns reduces coordination among contiguous towns regarding approval of subdivision regulations. With only half of the Catskill towns having subdivision regulations, this allows for the potential of an ill-conceived subdivision with no vehicle to regulate its occurrance.

In assessing the status of local land use planning in the Catskill Region, it appears that although five counties have county planning departments, their capabilities are limited and their legal powers are severely restricted.

The county planning agencies do not have the support from the localities to be effective in the efforts to plan.

A comprehensive plan that addresses both private and publicly owned lands but requires enforcement of only public lands obscures the full intent of such a plan. Most of the towns and villages in the Region are sparsely populated and unable to hire a full time planner to carry out a comprehensive planning effort. A logical vehicle to formulate a comprehensive plan for each locality would be the county planning agencies. However this would serve the locality and/or the county without 
taking into account an intergovernmental comprehensive planning approach to deal with the effects of land speculation and development on a cross county basis.

Generally, the repercussions of poorly planned development tend to conform to geographical rather than political boundaries. In a mountaineous region like the Catskills, this problem poses serious consequences. The overabundance of second home communities within a specific area has an impact that is not limited to the towns and villages which may have approved this kind of development. It is specifically for this reason that a regional planning framework is necessary for the Catskills. Table VI summarizes most of the land use controls being exercised by towns and villages in the Catskills.

In the five Catskill counties there are 75 towns and 27 villages. Ninety-three percent of the towns have planning boards, 56 percent have subdivision regulations and 36 percent have zoning ordinances in effect. Of the 27 villages 78 percent have planning boards, 37 percent have subdivision regulations and 63 percent have zoning ordinances. 
Table VI

STATUS OF LOCAL PLANNING, BY COUNTY (1978)

Planning Comprehensive

Board Planning

Subdivision 1 Zoning Regulations $^{1}$ Ordinance ${ }^{1}$

\begin{tabular}{lrrll}
\hline & & & & \\
Delaware County & 1 & 1 & No & NA \\
19 towns & 15 & 5 & 2 & 2 \\
11 villages & 7 & 7 & 0 & 6 \\
Greene County c & 1 & 1 & No & NA \\
14 towns & 13 & 3 & 4 & 4 \\
5 villages & 5 & 4 & 3 & 4 \\
Schoharie & 1 & NI & No & NA \\
7 towns & 7 & NI & NI & NA \\
Sullivan & 1 & 1 & No & NA \\
15 towns & 15 & 7 & $13(1)$ & $9(4)$ \\
6 villages & 5 & 4 & 5 & $3(1)$ \\
Ulster & 1 & 1 & No & NA \\
1 City & 1 & 1 & 1 & 1 \\
20 towns & 20 & 3 & 20 & 15 \\
15 villages & 4 & & 4 & 4 \\
& & & & \\
NI- No information & & & & \\
NA- Not applicable & & & &
\end{tabular}

1 Numbers in parenthesis ( ) indicate regulations in prepararion Source: Catskill Center for Conservation and Development, 1978 
Table VII

COUNTY PLANNING BOARD POWERS AND AC'TIVITIES

Functions Delaware Greene Schoharie Sullivan Ulster

Advisory

1. County Wide YES YES YES YES YES Studies

2. Local

YES

YES YES

YES

YES

Assistance

Planning

1. Comprehensive Ongoing Ongoing Ongoing Ongoing Ongoing Planning Element 701

b. Housing 701

2. Official

County Map

Update ${ }^{3}$ Ongoing

Update ${ }^{3}$

Ongoing Ongoing

Ongoing Ongoing

NO NO NO

NO

Review

1. Municipal sub YES

division regs

NO YES

NO

NO

2. Municipal zoning YES ordinances

YES

YES

YES

YES

$\&$ changes

3. A-95 Project NO

Review

NO

NO

YES

YES

Regulatory

County Subdivision NO

regulations

NO

NO

NO

NO

Budget (1977-78)

$$
\$ 60,000
$$

$\$ 84,000$

$\$ 30,000$

$\$ 60,000$

$\$ 42,000$

Funding (1977-78)

1. 701 Monies

NO

$\$ 25,500 \$ 12,000$

$\$ 25,500$

$\$ 42,000$

1. County planning board must be granted this power by county legislature

2. Not funded by 701

3. Land Use and Housing Elements are proposed for update next year to meet 701 requirements.

4. 701 monies shown include federal share(2/3 of total) state share(1/6 of total) and recipient's share( $1 / 6$ of total).

Source: Catskill Center for Conservation and Development(1977) 


\section{Footnotes}

1. Department of Environmental Conservation, 1976, "The Status of Regional, County, and Local Planning in the Catskills, Albany, p. 6.

2. Ibid p. 8

3. Ibid p. 11

4. Temporary State Commission to Study the Catskills, 1976, Interim Report, Stamford, New York, p. 22. 
Chapter IV

\section{Proposed Solutions}

The absence of adequate land use controls and the need for a regional approach to land were factors that led to the establishment of a Temporary State Commission to Study the Catskills. It was different from most state study commissions because rather than being limited to one or two matters of concern, the Study Commission was directed to study and recommend improvement for, virtually all aspects of the quality of life within the region.

It appears that the decision of the Catskill Study Commission to "study and recommend improvement for, all aspects of the quality of life within the region" is rather broad and loosely defined. Although there are many important issues regarding the "quality of life" in the Catskills, a temporary commission which is working under time and fiscal restraints must have a sharp focus regarding its purpose.

The following is an account of the legislative decision to conduct the Study.

"The Commission shall make a study of the Catskill Region which shall include, but not be limited to, the conservation and development of the region, notably the flora, fauna, scenic beauty and environmental purity; the strengthening of cultural resources, social organizations, economy and general well being of the rural communities and the development of measures by which the region may draw strength from neighboring cities but at the same time protecting itself from unplanned population 
growth. Also studied should be the development of controls for highways, public buildings and utilities; increased recreational facilities including the feasibility of greater water supply reservoirs; the measures to be taken by local governments to assure that the development of private lands is consistent with long range plans."

From its investigations, the Catskill Study Commission was convinced that a comprehensive regional approach to the subject matter was of vital importance to the well being of the Catskills. The pace of change in the Region had never been as great. It is important that the Region come to the realization of where it is and where it is heading so that some direction may be brought to the forefront that will permit controlled growth without imperiling the irreplaceable natural assets of the region.

However, the Commission failed to realize that a comprehensive regional approach could not be gained by making recommendations for all aspects of Catskill life. The economic, social and political diversity of the region makes this unattainable, rather the Commission's focus should have addressed one area. The first priority in this region is the need for land management, so that the area can accomodate a population growth, and at the same time, to retain the beauty and integrity of the Region.

The Commission however did recognize land management as a major issue of concern.

Several goals were discussed as part of the Commission's 
recommendations.

* Administrative and legislative changes to simplify, clarify and better enforce existing and proposed land use and development controls at the state, county and community levels.

The nature of this recommendation is important however it lacks specific administrative and legislative proposals necessary to encourage utilization of land use controls. Due to the limited degree of land use planning in the Region an evaluation of the administrative capabilities of the state, county and community planning departments is necessary.

There are a number of effective methods that a county planning agency may use to promote the establishment of local land use controls. The encouragement to create local conservation commissions would serve to inform the localities of the need for local land use controls.

In an assessment of the administrative review authority granted to the county planning agencies, it would serve the county's best interests if the review authority granted to them did not have a limited physical radius in which to review zoning ordinances and applications.

Another area that is in need of legislative change is the regulatory powers granted to the county planning agencies. The fact that a locality is not required to have subdivision regulations nor can the county require this regulation within a town's jurisdiction, may permit a subdivision with negative consequences. 
The provision of the review authority and regulatory powers of the county planning agencies need to be expanded through state legislative procedures, however, this would not sufficiently remedy the regionwide issues.

The powers granted to the county planning agencies apply to all New York State Counties without differentiating between each county's individual needs. It has been described that the Catskill counties share many common problems for which only a region wide approach will be adequate.

* Development and publication of land use and land capacity information to provide a thorough analysis of the Region's resources.

This is an important tool which is of primary importance to land use planning. Prior to effective land management of the Catskills, a current data base of existing land use should be required. A soil survey should be conducted which would classify and analyze the capability of the 1 and to withstand development.

* Maintenance of a viable agricultural economy and preservation of good and high quality agricultural lands in agricultural use.

This is one area in which the Catskill Study Commission made some significant substantive proposals. Based on the fact that "approximately $26 \%$ of all privately owned land in the region is occupied by more than 4,800 farms and that the dollar value of agriculture in the Catskill Region is larger than in all of 
Connecticut, and nearly as large as in all of New Jersey," the importance of agriculture to the economy of the Region makes it imperative that a viable agriculture be maintained and that high quality land be preserved for agricultural use. In addition to food, farming provides taxpaying open space and undeveloped areas which enhance the scenic beauty of the region. Farming insures that productive land is kept available for future food supply; and at the same time provides the basis of the rural character which distinguishes country from city.

The Catskill Study Commission had recommended viable techniques regarding the preservation of agricultural land in the Catskill Region.

\section{Agricultural Districts}

The Agricultural District Law is a useful device for maintaining active agricultural land in the Catskill Region. The law is not a permanent preserver of farmland but can slow the shift of farmland to other uses. The value of the law to the individual farmer is directly related to the development pressure on his and adjacent land. "Presently in the region there is in existence, or in the process of formation, 35 agricultural districts containing 393,584 acres.

\section{Purchase of Development Rights}

A second technique that may be used to preserve agricultural land is the ourchase of development rights. The use of agricultural zoning by the state to permanently preserve agricultural land 
for future agricultural use must prohibit other conflicting uses. Agricultural zoning alone cannot achieve this objective unless there is total restriction of land use to agriculture only. The purchase of development rights would restrict the owner's right for use and development of his land, but would provide compensation for this restriction. It appears that the state would be the logical level for the purchase of development rights.

Assessment of Land Development Project Impact

At the present time, there is no uniform or clearly defined technique for accurately assessing the impact of proposed projects on agricultural land. It is recommended that the New York State Department of Agriculture in conjunction with other agencies, develop guidelines to be used statewide to correct the situation. Included for assessment should be factors such as site features, soil resources, effects on farm efficiency and long range projections of economic loss due to displacement of farming and its effect on agriculture.

A major task of a regional agency would be to review and make recommendations on the regional impact of each development. This should not be limited to developments involving agricultural land but rather all major developments that might have regional impact. 
During the tenure of the Catskill Study Commission, several issues were studied and discussed. As the original legislative decision had mandated, virtually all aspects of Catskill life were examined.

Although the Study Commission recommends a regional approach in addressing the rapidly changing environment, it fails to define its focus. An area for which a regional body is recommended must have a clear and compelling rationale. Otherwise, there will be resistance from the local and county jurisdictions. This was the case in the Catskills whereby the local governments were uncomfortable with the massive scope of the Study Commission's intent. The mutual agreement was that land use problems caused by uncontrolled land development was the single most important Catskill issue that emerged from the Study Commission.

After expiration of the Study Commission, it was recommended that their work be continued but limited to land use and management-related issues. The New York State Department of Environmental Conservation was chosen by the legislature and the governor to complete the work done by the Study Commission.

It was the intent of the DEC to develop legislative proposals that would accurately reflect the needs to improve land use planning and management in the Catskills.

The DEC found that present state authority for land management in the region is partial and disconnected because existing state regulation apply to only some features, areas or projects each to a differing degree without the benefit of 
overall integration. They also felt that it was incomplete because it does not cover the adverse cumulative effects of small scale developments and activities that in the absence of effective local comprehensive planning and land use controls are threatening the future integrity of the Catskills.

In light of their findings, the Department of Environmental Conservation believed that the highest priority for the Catskills was the establishment of an improved institutional and operational framework for land resources management.

The DEC recommended the creation of a Regional Land Resources Management Commission.

"A permanent Catskill Regional Land Resources Management Commission should be established to provide a focal point for Catskill concerns and particularly for development and administration of the region. The Commission should be a state agency and therefore it should be established in the Executive Department of the state."

A recommendation to establish a Catskill Commission as a state agency would not be appropriate since much of the protest by Catskill residents is for county and local autonomy. An autonomous Commission might be more acceptable to the Catskill communities. In addition, a commission that is located in Albany, New York would reduce the communication network among Catskill counties. A Commission located in a central Catskill location 
overall integration. They also felt that it was incomplete because it does not cover the adverse cumulative effects of small scale developments and activities that in the absence of effective local comprehensive planning and land use controls are threatening the future integrity of the Catskills.

In light of their findings, the Department of Environmental Conservation believed that the highest priority for the Catskills was the establishment of an improved institutional and operational framework for 1 and resources management.

The DEC recommended the creation of a Regional Land Resources Management Commission.

"A permanent Catskill Regional Land Resources Management Commission should be established to provide a focal point for Catskill concerns and particularly for development and administration of the region. The Commission should be a state agency and therefore it should be established in the Executive Department of the state."

A recommendation to establish a Catskill Commission as a state agency would not be appropriate since much of the protest by Catskill residents is for county and local autonomy. An autonomous Commission might be more acceptable to the Catskill communities. In addition, a commission that is located in Albany, New York would reduce the communication network among Catskill counties. A Commission located in a central Catskill location 
within the Region, with possibly a satellite office would be more accessible to the county planning agencies and other similar planning efforts.

It appears that the DEC's recommendation for a Land Resources Management Commission is rather narrowly concerned with strictly environmental issues instead of broadening its approach to focus on strengthening the level of land use planning and controls in the Region.

"The Commission should be comprised of members from each of the Catskill Counties of Delaware, Greene, Schoharie, Sullivan and Ulster. The other members should "at large" and may be residents of the Catskills region or may reside outside of it within the state. In addition, the Commissioner of Environmental Conservation and the Secretary of State should be ex-officio voting members."

This requirement is important in that it serves to encourage participation on a county basis. The recommendation of having "at large" members is appropriate, however, they should consist exclusively of Catskill residents. The requirement to include the Commissioner of the Department of Environmental Conservation and the Secretary of State would violate local autonomy. The DEC has recommended that the Commission be an operating agency. It appears however that a coordinating agency would would be more acceptable to the towns and villages. The needs of the region are more aptly described as lacking 
coordination among the local and county jurisdictions regarding planning and land use controls.

A recommendation for a coordinating agency might also serve as a vehicle for encouraging a greater sense of regional identity among the Catskills counties. Another facet that should be included in the scope of a Catskill Commission would be to assist in the preparation of a regional land management plan in the form of the planning function. This plan should be described as a policy plan to guide conservation and development for the entire region. The Commission would serve in a technical assistance capacity to offer expertise to each Catskill county in the preparation of a land management plan for its jurisdiction within the region.

The Commission should integrate the county plans into a regional plan; modifying them only insofar as they may not meet the criteria initially established to assure consistency with the regional plan. The Commission should adopt the plan and provide recommendations for legislative implementation.

Prior to actual legislation being introduced, public hearings should be held throughout the Catskill Region so that there will be a high degree of citizen opinion into the legislative recommendations. This would also increase awareness among the various localities as to the importance of coordination of planning efforts.

Although it would be encouraging to see implementation of a regional land management plan, the possibility of this happening 
in the near future is remote. One overriding factor is the lack of a sense of regionalism in the Catskills. The vast social, economic and political diversity in the Region defies the easy identification of a regional mission. It is more appropriate then that a coordinating agency rather than an operating agency with actual enforcement powers be the realistic approach to land management in the Catskills. Potentially, after gaining a greater degree of coordination among the localities, discussion can begin regarding an operating agency in the Region with actual enforcement powers.

The establishment of a Catskill Regional Commission should stress that local governments should exercise their responsibility for land management and development.

"The inequity and inefficiency of a situation where one community assumes its proper responsibility for land management and the neighboring community defaults, thereby undercutting the first community and regional environmental balances, is a serious problem in need of correction."

"Planning determinations should be made with an understanding that the world does not stop at either the front doorstep of an individual or the boundary of a single municipality. Although individual and collective community needs are the major planning concerns, the broader public interest must be represented."

Not only should all communities exercise their home rule authority in these matters, but they should do it in a manner that will assure sound management of land that has regional and statewide implications. 


\section{Footnotes}

1. Department of Environmental Conservation, 1976, "Land Resources Management in the Catskills: Assessment and Recommendations", 1976, Albany, New York, p. 21

2. Ibid, p. 22 . 
Conclusion

For lack of local land use planning, the Catskill Region in recent years has witnessed a number of environmental blunders; new construction in flood plain areas, septic fields discharging wastes in adjacent streams, mobile homes placed in any convenient lot and strip development along highways.

Resistance to governmental planning runs deep in the Catskills. Many individuals view the town planner as a threat to private property rights. The town planner sees the county planner as a threat to home rule while the county planner sees the regional planner as a threat to county autonomy. Land use planning as an activity does occur in the region, however it is rather limited in scope. At present more than half of the cities and towns in the Catskills are without subdivision regulation or zoning ordinances.

Throughout the region, development has taken its toll on the land. Second home development and unplanned subdivisions are a major cause of the negative environmental effects occurring in the region. Tax assessment practices in New York State, in which land is usually assessed according to its potential for development rather than its existing use, encourage owners of large tracts of land to sell or develop their properties. Many farmers are coming under increasing pressure to sell. Thus, the number of farms in the Catskill Region is rapidly decreasing and land speculation companies are showing an increased interest in the area, paying little if any attention to the agricultural 
potential of the land.

It is among these reasons that citizen interest helped create the Temporary State Commission to Study the Catskills. The Commission was the first organized attempt to recognize the need for a comprehensive regional approach to the land development problems in the Catskills. The Commission was seeking ways for the Catskills to accomodate population growth and changes in technology to improve the quality of life as well as preserve the unique environmental quality of the Region.

A closer step towards the creation of a Catskill Regional Commission was a series of studies conducted by the New York State Department of Environmental Conservation. Their task was to complete the work done by the Temporary State Commission. Among the major recommendations of the Department of Environmental Conservation was the establishment of an improved institutional and operational framework for land resources management which would take the form of a permanent Catskill Regional Resources Management Commission. The Commission would establish guidelines and criteria for the preparation of a regional land resources management plan which would be described as a policy plan to guide conservation and development.

The culmination of the DEC studies led to a discussion of the development of legislation for a permanent Catskill Regional Agency. The DEC felt a major requirement to be incorporated into the legislation was that all local governments must exercise their responsibility for land conservation and development. Present local planning efforts are fragmented by the Region's 
division into one-hundred-and-two local jurisdictions. Individual local planning decisions are unable to respond effectively to often times inter-municipal and intercounty impacts resultant from their action.

The specific need for a Catskill Regional Commission is that it's important to provide a coordinating regional focus for local planning that considers the needs of the region as a whole while not threatening local autonomy. Without such comprehensive planning, the cumulative effect of local decisions made in isolation will be a continued erosion of the localities and irreplaceable natural beauty that gives the Catskill Region it's unique distinction. 
Bibliography

Adirondack Park Agency, Adirondack Park Land Use and Development Plan and Recommendations for Implementation. March 1973.

Bryant, William and Conklin Howard, "New Farmland Preservation Programs in New York State", Journal of the American Institute of Planners, November 1975, pp. 390-396.

Evers, Alf, The Catskills: From Wilderness to Woodstock, Doubleday and Company. Garden City, New York, 1972.

Leavitt, Sidney, "Common Sense Would Make Catskill Commission An Asset", The Daily Freeman, Kingston, New York, March 16,1977.

Miner, Dallas, "Agricultural Preservation: A New Issue in Open Space Consideration, "Environmental Comment, October 1974.

Natural Resources Defense Council, Land Use Controls in New York State, Dial Press/James Wade, New York, 1975.

New York State Department of Environmental Conservation, Analyzing the Potentials for Community Development and Agriculture in the Catskill Region, Albany, 1976

New York State Department of Environmental Conservation, Critical Features and Areas of the Catskills: A Summary, Albany, $1 \overline{976 .}$

New York State Department of Environmental Conservation, An Evaluation of Selected DEC Programs in relation to Land Resources Management, Albany 1976.

New York State Department of Environmental Conservation, Inventory of Lands in Public Ownership in the Catskills, Albany, 1976.

New York State Department of Environmental Conservation, Land Resources Management in the Catskills: Assessment and Recommendations, Albany, 1976.

New York State Department of Environmental Conservation, The Role of New York City Water Supply Lands in the Catskills, Albany, 1976.

New York State Department of Environmental Conservation, The Status of Regional, County and Local Planning Activities in the Catskilis, Albany, 1976.

New York State Department of Environmental Conservation, State Lands Master Plan, Albany, 1976.

New York State Department of Environmental Conservation, USDA Programs in the Catskill Region, Albany, 1976. 
Peterson, Craig A. and McCarthy, Claire, "A Proposal for an Agricultural Land Preservation Program, Land Use Law and Zoning Digest, v. 29, no. 8 pp. 4-8

Raup, Phillip M. , "Urban Threats to Rural Lands: Background and Beginnings", Journal of the American Institute of Planners, November 1975, pp. 371-378.

Sampson, Neil "Development on Prime Farmland", Environmental Comment, January 1978 , pp. 4-6

Temporary State Commission to Study the Catskills, The Future of the Catski11s, Stamford, New York, 1975.

Temporary State Commission to Study the Catskills, Interim Report, Stamford, New York, 1974.

"Ulster County Favors Catski11 Commission", Woodstock Times, March 10, 1977, p. I 